\title{
HIV-I, HSV-2 and syphilis among pregnant women in a rural area of Tanzania: Prevalence and risk factors
}

\author{
Khadija I Yahya-Malima*†1,2,3, Bjørg Evjen-Olsen ${ }^{\dagger 1,4}$, Mecky I Matee ${ }^{\dagger 5}$, \\ Knut Fylkesnes ${ }^{\dagger 1}$ and Lars Haarr ${ }^{\dagger 6}$
}

\author{
Address: ${ }^{1}$ Centre for International Health, University of Bergen, Bergen, Norway, ${ }^{2}$ School of Nursing, Muhimbili University of Health and Allied \\ Sciences, Dar es Salaam, Tanzania, ${ }^{3}$ School of Public Health Nursing, Ministry of Health, Morogoro, Tanzania, ${ }^{4}$ Haydom Lutheran Hospital, \\ Mbulu District, Manyara, Tanzania, ${ }^{5}$ Departments of Microbiology and Immunology, Muhimbili University of Health and Allied Sciences, Dar es \\ Salaam, Tanzania and ${ }^{6}$ The Gade Institute, Department of Microbiology and Immunology, University of Bergen, Bergen, Norway \\ Email: Khadija I Yahya-Malima* - khadija.malima@cih.uib.no; Bjørg Evjen-Olsen - bjorg.olsen@cih.uib.no; \\ Mecky I Matee - mateerrr@yahoo.com; Knut Fylkesnes - knut.fylkesnes@cih.uib.no; Lars Haarr - lars.haarr@vir.uib.no \\ * Corresponding author †Equal contributors
}

Published: 2 June 2008

BMC Infectious Diseases 2008, 8:75 doi:10.1 186/1471-2334-8-75
Received: 25 July 2007

Accepted: 2 June 2008

This article is available from: http://www.biomedcentral.com/I47/-2334/8/75

(c) 2008 Yahya-Malima et al; licensee BioMed Central Ltd.

This is an Open Access article distributed under the terms of the Creative Commons Attribution License (http://creativecommons.org/licenses/by/2.0), which permits unrestricted use, distribution, and reproduction in any medium, provided the original work is properly cited.

\begin{abstract}
Background: Evidence suggests that a substantial proportion of new HIV infections in African countries are associated with herpes simplex virus type 2 (HSV-2). Thus, the magnitude of HSV-2 infection in an area may suggest the expected course of the HIV epidemic. We determined prevalence of genital herpes, syphilis and associated factors among pregnant women from a remote rural Tanzanian community that has a low but increasing HIV prevalence.
\end{abstract}

Methods: We analysed 1296 sera and responses to a standard structured questionnaire collected from pregnant women aged between 15-49 years, attending six different antenatal clinics within rural Manyara and Singida regions in Tanzania. Linked anonymous testing (with informed consent) of the serum for specific antibodies against HSV-2 was done using a non-commercial peptide- 55 ELISA. Antibodies against syphilis were screened by using rapid plasma reagin (RPR) and reactive samples confirmed by Treponema pallidum haemagglutination assay (TPHA).

Results: Previous analysis of the collected sera had shown the prevalence of HIV antibodies to be $2 \%$. In the present study the prevalence of genital herpes and syphilis was $20.7 \%(95 \% \mathrm{Cl}$ : $18.53-$ $23.00)$ and $1.6 \%(95 \% \mathrm{Cl}: 1.03-2.5 \mathrm{I})$, respectively. The presence of HSV-2 antibodies was associated with polygamy (OR $2.2,95 \% \mathrm{Cl}$ : I.62 - 3.0I) and the use of contraceptives other than condoms (OR I.7, 95\% Cl: I.2I - 2.4I). Syphilis was associated with reporting more than one lifetime sexual partner (OR 5.4, 95\% Cl: I.88 - 15.76) and previous spontaneous abortion (OR 4.3, $95 \% \mathrm{Cl}:$ I.52-12.02).

Conclusion: The low prevalence of HIV infection offers a unique opportunity for strengthening HIV prevention in a cost-effective manner. The identification and control of other prevalent curable STIs other than syphilis and specific intervention of HSV-2 in specific populations like pregnant women would be one among approaches towards preventing incident HIV infections. 


\section{Background}

There is strong evidence that a substantial proportion of new HIV infections in African countries are associated with herpes simplex virus type 2 (HSV-2) [1-6]. Infection with HSV-2 has a significant impact on the risk of HIV acquisition and the impact increases as the HIV epidemic progresses $[7,8]$. One reason for this association could be the relative importance of HSV-2 in genital ulcer disease (GUD) in Africa has increased markedly. Infection with HSV-2 disrupts the genital mucosa and provides a portal of entry for HIV, leading to increased susceptibility of HIV in HIV-negative persons. In HIV-positive persons, infection with HSV-2 accelerates replication and genital shedding of the virus, thus such individuals are more likely to transmit HIV [9]. Studies from sub-Saharan countries have reported a high prevalence of HSV-2 in adults ranging from $30 \%$ to $80 \%$ in women and up to $50 \%$ in men $[5,10,11]$. In Tanzania, recent studies have shown HSV-2 represents $71 \%$ to $83 \%$ of all identified pathogens in genital ulcers $[12,13]$. Thus, the magnitude of HSV-2 infection may suggest the expected course of the HIV epidemic.

Tanzania is among the countries with a stabilised HIV epidemic. The estimated adult HIV prevalence was $8 \%$ by the end of 2004 based on data from the Tanzania HIV/AIDS indicator survey [14], closely matching HIV estimates $(8.7 \%)$ reported from antenatal clinic surveillance in the same year [15]. The HIV prevalence (2\%) in Manyara region by the end of 2004, matched with the estimate pregnant women attending local clinics within rural Manyara and Singida regions $[14,16]$. In the antenatal group, young women (15-19 years) presented with the highest prevalence $(3.0 \%)$ and in the general population, men aged 35-49 years $[16,17]$. In comparison with other regions in Tanzania, the HIV prevalence is still low [14]. The magnitude of HSV-2 in the same area is largely unknown, while the prevalence of syphilis among pregnant women was $17 \%$ as reported by a previous study within the area [18]. Unlike genital herpes, studies exploring syphilis as a GUD enhancing HIV susceptibility and infectiousness in high-risk groups have revealed conflicting results $[19,20]$. The limitations have been due to either a few number of syphilis cases or case ascertainment by self-reports rather than laboratory confirmed results. In Tanzania, 51\% of all stillbirths are associated with maternal syphilis [21]. Analysis of maternal syphilis and HIV prevalence among pregnant women attending selected antenatal clinics in by the end of 2004 showed geographical variation in the prevalence [22]. Rural antenatal clinics had high prevalence of syphilis $(9.5 \%)$ and low HIV prevalence $(5.2 \%)$ compared with other sites (6.8\% syphilis vs. $9.3 \%$ for HIV). The high prevalence was associated with lack of formal education, inadequate access to health care and poverty $[23,24]$. Thus to determine the prevalence of syphilis and genital herpes in this rural area with low but increasing HIV prevalence, we analysed antibodies against HSV-2 and Treponema pallidum. We used data and serum samples collected from a previously reported antenatal survey [16].

\section{Methods \\ Study area and population}

The current study was part of the epidemiological study conducted within the remote rural areas of Manyara and Singida in Tanzania. The area falls within the service catchment area of Haydom Lutheran Hospital (HLH). The main focus aimed towards understanding the epidemiological context of HIV in the area as part of the comprehensive prevention-intervention programme launched by the hospital to combat HIV and other sexually transmitted infections in the area [25]. Part of the interventions included voluntary counselling and testing for HIV (VCT), syphilis and HSV-2. Education provided for participants included HIV- related preventive education and benefits of highly active antiretroviral treatment (HAART) for prevention of mother to child transmission (PMTCT) explained, according to national guidelines for care and treatment of people living with HIV and AIDS.

\section{Sampling}

The survey included six antenatal clinics within the three administrative divisions that comprised the abovedefined catchment area, between November 2003 and April 2004, and the study population is described in detail [16]. In brief, it included all counselled and consenting pregnant women aged between 15-49 years attending six local antenatal clinics (ANC) for the first time in that particular pregnancy during the surveillance period. Two clinics from each administrative division were included. Based on previous estimates of HIV, HSV-2 and syphilis prevalence in the area, HIV prevalence was the lowest, so the sample size was based on that estimate. A sample size of 1000 pregnant women would allow us to calculate a $2 \%$ prevalence of HIV with $95 \%$ confidence intervals of 1 to $3 \%$. Point prevalence estimates of HIV, HSV-2 and syphilis are presented as the point estimate with their 95\% confidence intervals.

\section{Data collection tools and laboratory methods}

The research team collaborated with the hospital PMTCT teams in data collection. The PMTCT team was responsible for registration and coding of participant's identities and providing follow up care. The research team used a standard structured questionnaire to obtain information regarding socio-demographic and sexual behaviour characteristics. Included in the questionnaires were marital status, self-reported history of sexually transmitted infections and genital ulcers, the use of condoms and other contraceptives, and sexual partners. Blood was collected using vacutainers, and prepared serum samples were 
stored in the refrigerator and tested for HIV antibodies and syphilis the next day. Following HIV and syphilis antibody testing, the samples were stored at $-80^{\circ} \mathrm{C}$ until analysis for HSV-2 antibodies. Screening for anti-HIV IgG antibody was performed anonymously using Bionor HIV$1 \& 2$ assay $^{\circledast}$ (BIONOR AS, Skien, Norway). Reactive samples were confirmed using Bionor HIV-1 \& 2 assay ${ }^{\circledR}$ (BIONOR AS, Skien, Norway). Screening for syphilis was done using Rapid plasma reagin (RPR) by Omega Immutrep-RPR ${ }^{\circledast}$, Omega Diagnostics, Alva, UK and the reactive samples were confirmed by TPHA (Immutrep TPHA ${ }^{\circledast}$, Omega Diagnostics, Alva, UK). Positive RPR and TPHA tests were considered to indicate current or untreated syphilis. Specific antibodies for HSV-2 were detected by the non-commercial peptide-55 Enzyme-linked immunosorbent assay as described elsewhere [26-28]. The assay is specific for reactivity with an epitop within glycoprotein $G$ of HSV-2 (gG2) and does not cross-react with Herpes simplex virus type 1 . Sensitivity and specificity of $100 \%$ and $98.4 \%$, respectively, have been reported [27].

The cut-off value was set at a mean absorbance of the negative controls plus five standard deviations. Tanzanian sera, initially analysed by the same assay and the results confirmed with a commercial HerpeSelect 1 and 2 Immunoblot IgG ${ }^{\circledR}$ (IB0900G) from Focus Technologies Inc. (USA), were used as positive and negative controls [29]. The Regional Committee for Medical, Health Research, and Ethics in Western Norway (REK) and the Tanzanian National Institute of Medical Research (NIMR) gave ethical approval for research exploring HIV, HSV-2 and syphilis within the mentioned area. Regional and District level Ethical approval was sought and granted. Oral informed consent was sought from individuals and they where informed of their right to refuse to participate with out any consequences.

\section{Statistical analyses}

Data were entered twice in Excel spreadsheets and analysed using Stata $9.2^{\circledR}$ (College station, Texas, USA). We assessed self-reported previous adverse pregnancy outcomes as a probable indicator of previous syphilitic infection for women with previous pregnancies. The age at first pregnancy was explored as an indirect measure of unprotected sexual intercourse. The prevalence of HSV-2 and syphilis was compared to the previously reported HIV prevalence in the same population of pregnant women to assess the coexistence of these infections. We define polygamous relationship as women with sexual relations with a man having more than one wife or sexual partner(s) at the same time and monogamous relation women in marriage or sexual relationship with a man who has no other but only one wife/sexual partner at the same time.
Logistic regression was used to explore potential risk factors for HSV-2 and syphilis. Since HSV2 antibodies remain for life in infected people, older pregnant women would be more likely to have antibodies from previously acquired HSV2 infections. We adjusted for age in the analysis of HSV-2 and risk factors to avoid overestimation in older women and underestimation in younger women thus allowing comparison of the risk of HSV-2 infection.

Variables with p-values less than 0.25 on age-adjusted analysis were included in the final multivariate model and the associations presented as Odds ratios (OR) with a $95 \%$ confidence interval (CI).

\section{Results}

In a sample of 1377 consenting pregnant women, 1296 women completed interviews and provided serum samples for laboratory testing. Four per cent of women (58/ 1377) declined a blood test, and we discarded 1.7\% (23/ 1319) haemolysed samples. The mean age of the studied population was $26.3(\mathrm{SD} \pm 6.1$ ) years and the mean age at first pregnancy was $19(\mathrm{SD} \pm 3$ ) years. Ninety-one per cent of the women were married (Table 1) and $79 \%$ of them reported monogamous marriage while $28 \%$ of all women had no formal education.

Table 1 summarizes results on HSV-2 prevalence and associated factors. The overall prevalence of HSV-2 was 20.7\% (95\% CI: 18.53-23.00), varying between $7.0 \%$ and $32.9 \%$. HSV-2 prevalence increased with age, ranging from $19 \%$ in the 15-19 year age group to $27 \%$ among women aged 35 years or older. The prevalence was between $18 \%$ and $35 \%$ for all socio-demographic variables. Women in polygamous relationships, had high prevalence of HSV-2 (32.7\%, 95\% CI: 27.24-38.69) compared with women in monogamous relationships (17\%, 95\% CI: 15.23-19.90). HSV-2 prevalence did not differ with a history of condom use and only $4.9 \%$ of the women reported to have ever used condoms.

In age-adjusted analysis, the likelihood of HSV-2 antibodies was associated with a self-reported history of sexually transmitted infections, polygamous relationship, using non-condom contraceptives and more than one lifetime sexual partner. On multivariate analysis, all clinics except Basotu had high odds ratios of HSV-2 infection. Higher odds were particularly seen in Muslur (OR 6.8 (95\% CI: 3.76-12.27) and Dangayda clinics (OR 5.3 (95\% CI: 2.78 - 10.16), Table 1 right column. HSV-2 remained significantly associated with polygamous relationships, OR 2.2 (95\% CI: $1.62-2.99$ ) or the use of non-condom contraceptives OR 1.7 (95\% CI: 1.21-2.41) and weakly associated with more than one lifetime sexual partner (OR 1.8 (95\% CI: 1.04-3.04). We found no dual infections with HIV for those with HSV-2 antibodies (data not shown). 
Table I: The prevalence of genital herpes and associated factors among pregnant women

\begin{tabular}{|c|c|c|c|c|}
\hline Characteristics & $\mathbf{N}(\%)$ & $\begin{array}{c}\text { HSV-2 prevalence \% } \\
(95 \% \mathrm{Cl})\end{array}$ & Age-adjusted OR $(95 \% \mathrm{Cl})$ & $\begin{array}{c}\text { Multivariate analysis OR } \\
(95 \% \mathrm{Cl})\end{array}$ \\
\hline Total & 1296 & $20.7(18.53-23.00)$ & & \\
\hline \multicolumn{5}{|l|}{ Clinic } \\
\hline Basotu & $242(18.7)$ & $7.0(4.27-1 \mathrm{I} .2 \mathrm{I})$ & 1 & 1 \\
\hline Haydom & $319(24.6)$ & $23.8(19.33-28.86)$ & $4.2(2.4 I-7.3 I) *$ & $4.2(2.39-7.4 I) *$ \\
\hline Muslur & $192(14.8)$ & $32.8(26.32-40.00)$ & $6.5(3.63-11.52) *$ & $6.8(3.76-12.27) *$ \\
\hline Dangayda & $113(8.7)$ & $32.9(23.59-41.38)$ & $6.0(3.19-11.35) *$ & $5.3(2.78-10.16) *$ \\
\hline Mwanga & $249(19.2)$ & $20.1(15.40-25.7 I)$ & $3.3(1.86-5.95) *$ & $3.3(1.84-6.02) *$ \\
\hline Nduguti & $181(14.0)$ & $14.4(9.76-20.53)$ & $2.2(1.16-4.23) *$ & $2.2(1.15-4.24) *$ \\
\hline \multicolumn{5}{|l|}{ Age groups (years) } \\
\hline $15-19$ & $165(12.7)$ & $19.5(|3.9|-26.58)$ & 1 & \\
\hline $20-24$ & $417(32.2)$ & $19.4(15.80-23.62)$ & $1.0(0.63-1.57)$ & $0.8(0.48-1.28)$ \\
\hline $25-29$ & $349(26.9)$ & $17.4(13.69-21.90)$ & $0.9(0.54-1.40)$ & $0.7(0.4 I-1.13)$ \\
\hline $30-34$ & $224(17.3)$ & $24.5(19.58-31.30)$ & $1.3(0.82-2.19)$ & $0.9(0.55-1.61)$ \\
\hline$\geq 35$ & $141(10.9)$ & $27.7(20.62-35.93)$ & $1.6(0.92-2.69)$ & $1.0(0.56-1.77)$ \\
\hline \multicolumn{5}{|l|}{ Marital status } \\
\hline Married & $1183(91.3)$ & $20.9(18.62-23.33)$ & 1 & - \\
\hline $\begin{array}{l}\text { Single/divorced/separated/ } \\
\text { widow }\end{array}$ & $113(8.7)$ & $18.6(12.12-27.23)$ & $1.1(0.68-1.91)$ & \\
\hline \multicolumn{5}{|l|}{ Education (years) } \\
\hline None & $349(28.2)$ & $20.9(16.85-25.64)$ & 1 & - \\
\hline $1-6$ years & $174(13.4)$ & $17.8(12.60-24.49)$ & $0.8(0.51-1.40)$ & \\
\hline 7 years or more & $773(59.7)$ & $21.2(18.42-24.30)$ & $1.0(0.74-1.9)$ & \\
\hline \multicolumn{5}{|c|}{ a Polygamous relationship } \\
\hline No & $1024(79.0)$ & $17.5(15.23-19.90)$ & 1 & \\
\hline Yes & $272(21.0)$ & 32.7 (27.24-38.69) & $2.2(1.63-3.01) *$ & $2.2(1.62-2.99) *$ \\
\hline \multicolumn{5}{|l|}{ b Age at first pregnancy } \\
\hline$<18$ years & $158(14.0)$ & $23.4(17.21-30.94)$ & 1 & \\
\hline$\geq 18$ years & $974(86.0)$ & $20.4(17.97-23.13)$ & $1.2(0.85-1.73)$ & $1.2(0.82-1.70)$ \\
\hline \multicolumn{5}{|c|}{$\begin{array}{l}\text { Number of lifetime sexual } \\
\text { partners }\end{array}$} \\
\hline One only & $|23|(95.0)$ & $18.2(16.14-20.54)$ & 1 & \\
\hline More than one & $65(5.0)$ & $35.3(24.36-47.90)$ & $2.0(1.21-3.46) *$ & $1.8(1.04-3.04)$ \\
\hline \multicolumn{5}{|c|}{$\begin{array}{l}\text { Use of contraceptives other } \\
\text { than condom }\end{array}$} \\
\hline No & $1088(84.0)$ & $19.2(|6.93-21.7|)$ & 1 & $\mathbf{I}$ \\
\hline Yes & $208(16.0)$ & $28.4(22.45-35.09)$ & $1.7(1.20-2.37)^{*}$ & $1.7(1.2 I-2.4 I) *$ \\
\hline \multicolumn{5}{|l|}{$\begin{array}{l}\text { History of sexually } \\
\text { transmitted infections }\end{array}$} \\
\hline No & $1135(87.6)$ & $19.8(17.56-22.29)$ & 1 & \\
\hline Yes & $161(12.4)$ & $27.0(20.20-34.35)$ & $1.5(1.01-2.17)$ & $1.3(0.87-1.92)$ \\
\hline \multicolumn{5}{|l|}{ Ever used condom } \\
\hline No & $1233(95.1)$ & $20.6(18.47-23.07)$ & 1 & - \\
\hline Yes & $63(4.9)$ & $20.6(11.85-33.04)$ & I.I (0.56- I.97) & \\
\hline
\end{tabular}

aRelationship with a man having more than one female sexual partner regardless of marital status

${ }^{b}$ Analysed for those aged $20 \geq$ years at the time of survey

Total HSV-2 positive $(n=268 /$ I 296$)$

*P-values: $<0.01$ 
Age at first pregnancy was not associated with increased risk of HSV-2 antibodies (Table 1).

The overall prevalence of syphilis was $1.6 \%$, but was higher in women aged 20-24 years and 30-34 years (2.4\% and $3.1 \%)$ (Table 2). The highest prevalence of syphilis $(8.8 \%)$ was associated with more than one lifetime sexual partner, followed by self-reported spontaneous abortion $6.1 \%$. Women in polygamous relationships and those with a self-reported history of sexually transmitted infection had a prevalence of 3.7\% (95\% CI: $1.88-$ $6.87)$ and $3.1 \%$ (95\% CI: 1.15-7.48), respectively. None of those who had ever used condoms had antibodies against syphilis. Prevalence of syphilis in women aged less than 18 at first pregnancy was $2.5 \%$ (Table 2 ) and $1.7 \%$ for pregnancies at older age.

In multivariate analysis, women who reported previous spontaneous abortion as an adverse pregnancy outcome, were more likely to have a positive syphilis serology (OR 4.3, 95\% CI: 1.52-12.02) compared with those reporting stillbirth (OR 2.4, 95\% CI: 0.64-8.95). Odds were also higher for women who had more than one lifetime sexual partner, OR 5.4 (95\% CI: 1.88-15.76). Dual syphilis and HIV infection occurred in only one individual aged 30 years and this person had had more than one lifetime sexual partner. Eight of the 21 women with syphilis were infected with HSV-2 (OR 2.5, 95\% CI: 0.32 - 19.36), but the figures are too small to interpret the precise association. In addition, being less than 18 years at first pregnancy did not have a significantly increased risk of positive syphilis serology.

\section{Discussion}

The overall prevalence of HSV-2 antibodies among pregnant women in the rural Manyara and Singida regions in Tanzania was $20.7 \%$, varying from $7 \%$ to $33 \%$ between clinics and increasing with age. This is a slightly lower prevalence than observed by Obasi and colleagues in a different rural region in Tanzania (Mwanza) where 42\% of the women had HSV-2 antibodies [30]. The prevalence of syphilis in the present study (1.6\%) is much lower than previously observed $(17 \%)$ in this region, the finding may partly reflect the effect of syndromic management of STI imposed in health services since 1999 [31]. Our findings though suggestive of the relatively low HSV-2 and syphilis prevalence in the area compared to other places in Tanzania, point out a potential opportunity for indirect HIV prevention by controlling prevalent STIs.

Measurement of the HSV-2 antibodies was performed with a non-commercial method using a branched peptide with a sequence similar to a specific epitope in glycoprotein G of HSV-2 $[26,28]$. Commercial assays use the entire glycoprotein $G$, and may sometimes have problems with false positive results. When comparing performance of peptide 55 method with Western blot, we did not detect any false positive results in Tanzanian sera from persons 13 years old or older [32].

Studies from rural areas in Gambia in West Africa, using the peptide 55 method, have shown infection in 30\% of the studied women $[33,34]$. Other prevalence studies in urban regions of Tanzania have shown that $35 \%$ of pregnant women in Dar es Salaam [35] and 39\% of women attending primary health care clinics in Moshi were infected with HSV-2 [4]. Among STD patients in urban Mbeya and Dar es Salaam regions of Tanzania, HSV-2 was the most commonly $(71 \%)$ identified agent in genital ulcer specimens [12]. In these patients, detection of HSV2 was at significantly higher in HIV infected compared to those not infected [12]. Therefore, taken together, these results indicate a generalised HSV-2 infection in the Tanzanian population. Suggestions on the limited impact of HSV-2 on incident HIV infections in the early stages of the HIV epidemic may also hold true for this area [7]. Despite the generalised, stable HIV epidemic in Tanzania, the epidemiological patterns of STIs have shown regional variations on the level and magnitude, largely influenced by cultural, economical political and social factors. [14,17]. The prevalence of HSV-2 was significantly higher in all clinics compared to Basotu clinic but this village reportedly, had the highest HIV prevalence [17]. We are uncertain to the reasons that might explain this distribution. Basotu presents a very mixed population compared to the other villages, Lake Basotu may attract fishermen from other regions and in-migration of HIV infected persons is possible. Fishing provides a substantial economical gain that is lacking in other villages.

Our definition of positive syphilis serology would not only include those with infectious syphilis (primary and secondary), but also cases of untreated latent syphilis though persons in the latent syphilitic state are non-infectious. Reported estimates of the prevalence of syphilis in other rural antenatal sentinel sites in Tanzania in 2004 ranged from 14.9\% in Kagera and 2.1\% in Kigoma region. The corresponding prevalence of HIV was $4.7 \%$ and $5.1 \%$ respectively [15]. The later study performed RPR under field conditions, and lacked confirmatory tests for syphilis and likely to have overestimated prevalence of syphilis. Likewise, Kagera region is experiencing a different stage of the HIV epidemic compared to rural Manyara, Singida and Kigoma regions. Kagera was the first region in Tanzania to report AIDS cases and experienced a severe HIV epidemic (24.2\%) since 1987 and is low levelling off as a result of excessive mortality and multiple interventions [36]. While rural Manyara, Singida and Kigoma regions had relatively lower HIV prevalence in the last decade but have recently shown an increasing potential. Thus, the 
Table 2: The prevalence of syphilis and associated factors among pregnant women

\begin{tabular}{|c|c|c|c|c|}
\hline Characteristics & $\mathbf{N}(\%)$ & $\begin{array}{c}\text { Syphilis prevalence \% } \\
(95 \% \mathrm{Cl})\end{array}$ & $\begin{array}{l}\text { Age-adjusted OR (95\% Cl) } \\
\text { (p-value) }\end{array}$ & $\begin{array}{l}\text { Multivariate analysis OR } \\
(95 \% \mathrm{Cl})(\mathrm{p} \text {-value) }\end{array}$ \\
\hline Total & 1296 & $1.6(1.03-2.51)$ & & \\
\hline \multicolumn{5}{|l|}{ Age groups (years) } \\
\hline $15-19$ & $165(12.7)$ & 0 & - & - \\
\hline $20-24$ & $417(32.2)$ & $2.4(1.22-4.5 I)$ & & \\
\hline $25-29$ & $349(26.9)$ & $0.9(0.22-2.69)$ & & \\
\hline $30-34$ & $224(17.3)$ & $3.1(1.38-6.60)$ & & \\
\hline$\geq 35$ & $141(10.9)$ & $0.7(0.03-4.47)$ & & \\
\hline \multicolumn{5}{|l|}{ Marital status } \\
\hline Married & $1183(91.3)$ & $1.8(1.13-2.75)$ & & \\
\hline Single/divorced/separated/widow & $113(8.7)$ & 0 & - & - \\
\hline \multicolumn{5}{|l|}{ Education (years) } \\
\hline None & $349(28.2)$ & $2.3(1.07-4.64)$ & I & \\
\hline $1-6$ years & $174(13.4)$ & $1.7(0.45-5.36)$ & $0.8(0.20-2.85)$ & \\
\hline 7 years or more & $773(59.7)$ & $1.3(0.66-2.48)$ & $0.6(0.22-1.43)$ & - \\
\hline \multicolumn{5}{|l|}{ Polygamous relationship } \\
\hline No & $1024(79.0)$ & $1.1(0.57-1.98)$ & I & I \\
\hline Yes & $272(21.0)$ & $3.7(1.88-6.87)$ & $2.7(1.08-6.64)(p=0.03)$ & $2.6(1.06-6.5 I)(p=0.03)$ \\
\hline \multicolumn{5}{|l|}{ age at first pregnancy } \\
\hline$<18$ years & $158(14.0)$ & $2.5(0.81-6.76)$ & - & \\
\hline$\geq 18$ years & $974(86.0)$ & $1.7(1.05-2.84)$ & & \\
\hline \multicolumn{5}{|c|}{$\begin{array}{l}\text { Outcome of previous pregnancy ( } \mathrm{n} \\
\equiv=1155)\end{array}$} \\
\hline Live child & $916(79.3)$ & $1.3(0.71-2.34)$ & I & 1 \\
\hline Stillbirth & $140(12.1)$ & $2.1(0.55-6.62)$ & $1.6(0.45-5.92)$ & $2.4(0.64-8.95)$ \\
\hline Spontaneous abortion & $99(8.57)$ & $6.1(2.49-13.24)$ & $4.9(1.78-13.25)(p=0.00)$ & $4.3(1.52-12.02)(p=0.00)$ \\
\hline \multicolumn{5}{|l|}{$\begin{array}{l}\text { Number of lifetime sexual } \\
\text { partners }\end{array}$} \\
\hline One only & $|23|(95.0)$ & $1.2(0.71-2.05)$ & I & I \\
\hline More than one & $65(5.0)$ & $8.8(3.64-18.85)$ & $7.8(2.94-20.86)(p=0.00)$ & $5.4(1.88-15.76)(p=0.00)$ \\
\hline \multicolumn{5}{|c|}{$\begin{array}{l}\text { Use of contraceptives other than } \\
\text { condom }\end{array}$} \\
\hline No & $1088(84.0)$ & $1.8(1.16-2.88)$ & I & 1 \\
\hline Yes & $208(16.0)$ & $0.5(0.02-3.06)$ & $0.3(0.03-1.93)$ & $0.3(0.04-2.66)$ \\
\hline \multicolumn{5}{|l|}{$\begin{array}{l}\text { History of sexually transmitted } \\
\text { infections }\end{array}$} \\
\hline No & $1135(87.6)$ & $1.4(0.84-2.33)$ & I & 1 \\
\hline Yes & $161(12.4)$ & $3.1(1.15-7.48)$ & $2.2(0.81-6.20)$ & $1.8(0.60-5.18)$ \\
\hline \multicolumn{5}{|l|}{ Ever used condom } \\
\hline No & $1233(95.1)$ & $1.7(1.08-2.64)$ & - & - \\
\hline Yes & $63(4.9)$ & 0 & & \\
\hline
\end{tabular}

Total syphilis positive $(n=21 / 1296)$. Results for analysis of syphilis prevalence by clinic locations are not shown due to very small numbers or none-to give any substantial statistical inference.

a Analysed for those aged $20 \geq$ years at the time of survey $(n=1132)$

interpreting compared prevalence of syphilis with rural Manyara and Singida region is with caution. The proportion of active syphilis in our study might be lower than our prevalence estimates by using TPHA, since antibodies detected by this method remain for life. While, the use of Venereal Disease Research Laboratory (VDRL) test alone in the previous local study in 1999 might have overestimated the prevalence [18].
The low prevalence of HIV in our study (2.0\%) may explain why we did not detect an association between infections with HIV and HSV-2. The potential reason for the low prevalence was associated with remoteness and reduced mobility of the people within this rural area. High numbers of lifetime sexual partners have previously shown to increase the risk of acquiring infection with HSV-2 and syphilis $[4,35,37]$. These risk factors are also 
presented in this study, as shown in Tables 1 and 2 . Women in polygamous relationships presented with higher prevalence of HSV-2 (Table 2), in agreement with a report from Gambia [11]. In the present work as well as in others syphilis was shown to be a high probable risk for spontaneous abortion (Table 2) [38,39]. However, we did not find an association with stillbirth, even though $25 \%$ of the pregnancies might result in stillbirth in cases of maternal syphilis [21]. The lack of association in our study could be, partly due to confounding effects of other causes of stillbirth, beyond the scope of this study and the lower number of syphilis cases. Although sexual transmission of syphilis is usually limited to the early stages, vertical transmission is still possible in latency.

\section{Conclusion}

Though we cannot rule out the effect of other STIs on the level HIV infection presented, the identified risk factors for STI are similar to other areas in Tanzania that have experienced a higher level of HIV and related STIs. The low but changing prevalence of HIV infection offers a unique opportunity for strengthening HIV prevention in a cost-effective manner [40]. The identification and control of other prevalent curable STIs other than syphilis and specific intervention for HSV-2 in specific populations like pregnant women should be among approaches towards preventing incident HIV infections.

\section{Competing interests}

The authors declare that they have no competing interests.

\section{Authors' contributions}

All authors contributed substantially to the paper. All authors conceived the study. The first author conducted the study and performed HSV-2 serology, supervised by LH. BE-O and MIM supervised the fieldwork. KIY-M did the statistical analysis and interpretation. All authors helped to conceptualise ideas, interpret the findings and reviewed drafts of the manuscript.

\section{Acknowledgements}

We would like to acknowledge the "Gender Generation and Communication in these times of AIDS" project (GeGCA-NUFU), Bergen, Norway and the Centre for International Health, University of Bergen, Norway, for funding this study. We thank $\operatorname{Dr} \mathrm{G}$. Somi of the Epidemiology unit at the National AIDS control Programme in Dar es Salaam, Tanzania for his ideas on STI surveillance. Further, we thank the following for their contribution in the preparation for laboratory work; Ms Basra Doulla (Dar es Salaam, Tanzania) and Sissel Slettjord (Kristiansand, Norway). In the same capacity, Reidun Haegland, Kjerstin Jakobsen and Mabula Kasubi of the Department of Microbiology and Immunology, Gades Institute. We thank Arvid Nilsen of the Department of Dermatology, Institute of Medicine, and Lindsey Moore of the Department of Biology, University of Bergen for their contribution to the manuscript. We thank Howard Marsden for his important suggestions for the laboratory work. Further, we thank the antenatal clinic authorities of Rural Manyara and Singida regions and Haydom Lutheran Hospital and the Haydom Voluntary AIDS Control Programme
(HAVACOP). We would also like to acknowledge the research assistants and lastly, we thank the women who took part in the study.

\section{References}

I. Buve A, Carael M, Hayes R, Robinson NJ: Variations in HIV prevalence between urban areas in sub-Saharan Africa: do we understand them? Aids 1995, 9(Suppl A):SI03-109.

2. Auvert B, Ballard R, Campbell C, Carael M, Carton M, Fehler G, Gouws E, MacPhail C, Taljaard D, Van Dam J, et al.: HIV infection among youth in a South African mining town is associated with herpes simplex virus- 2 seropositivity and sexual behaviour. Aids 200I, I 5(7):885-898.

3. del Mar Pujades Rodriguez M, Obasi A, Mosha F, Todd J, Brown D, Changalucha J, Mabey D, Ross D, Grosskurth H, Hayes R: Herpes simplex virus type 2 infection increases HIV incidence: a prospective study in rural Tanzania. Aids 2002, I 6(3):45 I-462.

4. Msuya SE, Mbizvo E, Hussain A, Sam NE, Jeansson S, Stray-Pedersen $B$ : Seroprevalence and correlates of herpes simplex virus type 2 among urban Tanzanian women. Sexually transmitted diseases 2003, 30(7):588-592.

5. Weiss H: Epidemiology of herpes simplex virus type 2 infection in the developing world. Herpes 2004, I I(Suppl I):24A-35A.

6. Kapiga SH, Sam NE, Bang H, Ni Q, Ao TT, Kiwelu I, Chiduo S, Ndibe $U$, Seage $G$ 3rd, Coplan $P$, et al.: The role of herpes simplex virus type 2 and other genital infections in the acquisition of HIVI among high-risk women in northern Tanzania. J Infect Dis 2007, I 95(9): I 260-1269.

7. Freeman EE, Orroth KK, White RG, Glynn JR, Bakker R, Boily MC, Habbema D, Buve A, Hayes R: Proportion of new HIV infections attributable to herpes simplex 2 increases over time: simulations of the changing role of sexually transmitted infections in sub-Saharan African HIV epidemics. Sex Transm Infect 2007, 83(Suppl I):il 7-24.

8. Wald A, Link K: Risk of human immunodeficiency virus infection in herpes simplex virus type 2-seropositive persons: a meta-analysis. The Journal of infectious diseases 2002, I 85(I):45-52.

9. Ghys PD, Fransen K, Diallo MO, Ettiegne-Traore V, Coulibaly IM, Yeboue KM, Kalish ML, Maurice C, Whitaker JP, Greenberg AE, et al: The associations between cervicovaginal HIV shedding, sexually transmitted diseases and immunosuppression in female sex workers in Abidjan, Cote d'Ivoire. AIDS (London, England) 1997, I I( I 2):F85-93.

10. Weiss HA, Buve A, Robinson NJ, Van Dyck E, Kahindo M, Anagonou S, Musonda R, Zekeng L, Morison L, Carael M, et al:: The epidemiology of HSV-2 infection and its association with HIV infection in four urban African populations. Aids 200I, I 5(Suppl 4):S97-108.

II. Halton K, Ratcliffe AA, Morison L, West B, Shaw M, Bailey R, Walraven $G$ : Herpes simplex 2 risk among women in a polygynous setting in rural West Africa. Aids 2003, I 7(I):97-I03.

12. Ahmed HJ, Mbwana J, Gunnarsson E, Ahlman K, Guerino C, Svensson LA, Mhalu F, Lagergard T: Etiology of genital ulcer disease and association with human immunodeficiency virus infection in two Tanzanian cities. Sexually transmitted diseases 2003, 30(2): I |4- I 19.

13. Nilsen A, Kasubi MJ, Mohn SC, Mwakagile D, Langeland N, Haarr L: Herpes simplex virus infection and genital ulcer disease among patients with sexually transmitted infections in Dar es Salaam, Tanzania. Acta Derm Venereol 2007, 87(4):355-359.

14. Tanzania Commission for AIDS, National Bureau of Statistics, ORC Macro: Tanzania HIVIAIDS Indicator Survey 2003-2004. Calverton, Maryland, USA: Tanzania Commission for AIDS, National Bureau of Statistics and ORC Macro; 2005.

15. Ministry of Health The United Republic of Tanzania National AIDS Control Programme: HIVIAIDS/STD Surveillance Report no 19, 2004. Dar es Salaam: Epidemiology unit NACP.

16. Yahya-Malima KI, Olsen BE, Matee MI, Fylkesnes K: The silent HIV epidemic among pregnant women within rural Northern Tanzania. BMC Public Health 2006, 6:109.

17. Yahya-Malima KI, Matee MI, Evjen-Olsen B, Fylkesnes K: High potential of escalating HIV transmission in a low prevalence setting in rural Tanzania. BMC Public Health 2007, 7:103. 
18. Hinderaker SG, Kruger C, Olsen BE, Naman N, Bergsjo P, Olsen OH: Low HIV-seroprevalence in pregnant women in a rural area in Tanzania. Acta Obstet Gynecol Scand 200 I, 80 (I 2): I I52-I I 53.

19. Nelson KE, Eiumtrakul S, Celentano D, Maclean I, Ronald A, Suprasert S, Hoover DR, Kuntolbutra S, Zenilman JM: The association of herpes simplex virus type 2 (HSV-2), Haemophilus ducreyi, and syphilis with HIV infection in young men in northern Thailand. J Acquir Immune Defic Syndr Hum Retrovirol 1997, 16(4):293-300.

20. Bakari M, Lyamuya E, Mugusi F, Aris E, Chale S, Magao P, Jossiah R, Janabi M, Swai A, Pallangyo N, et al.: The prevalence and incidence of HIV-I infection and syphilis in a cohort of police officers in Dar es Salaam, Tanzania: a potential population for HIV vaccine trials. AIDS (London, England) 2000, I4(3):3।3-320.

21. Watson-Jones D, Changalucha J, Gumodoka B, Weiss H, Rusizoka M, Ndeki L, Whitehouse A, Balira R, Todd J, Ngeleja D, et al.: Syphilis in pregnancy in Tanzania. I. Impact of maternal syphilis on outcome of pregnancy. The Journal of infectious diseases 2002 I 86(7):940-947.

22. Swai RO, Somi GR, Matee MI, Lyamuya EF, Killewo J, Kwesigabo G, Tulli T, Kabalimu TK, Ng'ang'a L, Isingo R, et al.: Surveillance of HIV and syphilis infections among antenatal clinic attendees In Tanzania-2003/2004. BMC Public Health 2006, 6(I):9I.

23. Gloyd $S$, Chai $S$, Mercer MA: Antenatal syphilis in sub-Saharan Africa: missed opportunities for mortality reduction. Health Policy Plan 200I, I 6(I):29-34.

24. Watson-Jones D, Gumodoka B, Weiss H, Changalucha J, Todd J, Mugeye K, Buve A, Kanga Z, Ndeki L, Rusizoka M, et al.: Syphilis in pregnancy in Tanzania. II. The effectiveness of antenatal syphilis screening and single-dose benzathine penicillin treatment for the prevention of adverse pregnancy outcomes. The Journal of infectious diseases 2002, 186(7):948-957.

25. Haydom Lutheran Hospital: HIVIAIDS policy outline: Risk, vulnerability and impact. Integrating modern and traditional strategies. Hanang: Haydom Lutheran Hospital; 2003:6-8.

26. Marsden HS, MacAulay K, Murray J, Smith IW: Identification of an immunodominant sequential epitope in glycoprotein $\mathbf{G}$ of herpes simplex virus type 2 that is useful for serotype-specific diagnosis. I Med Virol 1998, 56(I):79-84.

27. Nilsen A, Ulvestad E, Marsden H, Langeland N, Myrmel H, Matre R, Haarr L: Performance characteristics of a glycoprotein $\mathbf{G}$ based oligopeptide (peptide 55) and two different methods using the complete glycoprotein as assays for detection of anti-HSV-2 antibodies in human sera. J Virol Methods 2003, I 07(I):2I-27.

28. Oladepo DK, Klapper PE, Marsden HS: Peptide based enzymelinked immunoassays for detection of anti-HSV-2 IgG in human sera. J Virol Methods 2000, 87(I-2):63-70.

29. Kasubi MJ, Nilsen A, Marsden HS, Bergstrom T, Langeland N, Haarr $L$ : A branched, synthetic oligopeptide corresponding to a region of glycoprotein G of HSV-I reacts sensitively and specifically with HSV-I antibodies in an ELISA. J Virol Methods 2005, I 25(2): 137-143.

30. Obasi A, Mosha F, Quigley M, Sekirassa Z, Gibbs T, Munguti K, Todd J, Grosskurth H, Mayaud P, Changalucha J, et al.: Antibody to herpes simplex virus type 2 as a marker of sexual risk behavior in rural Tanzania. The Journal of infectious diseases 1999, I 79(I):16-24.

31. National AIDS Control Programme: HIVIAIDS/STI Surveillance, Report No 19. Edited by: Swai R, Somi G, Killewo J, Lyamuya E, Matee MI, Kabalimu TS, Kwesigabo G, Tulli T, Isingo R, Ndayongeje J. Dar es Salaam, Tanzania: Epidemiology Unit, NACP. Ministry of Health, Tanzania Mainland; 2005.

32. Kasubi MJ, Nilsen A, Marsden HS, Bergstrom T, Langeland N, Haarr $L$ : Prevalence of antibodies against herpes simplex virus types $I$ and $\mathbf{2}$ in children and young people in an urban region in Tanzania. J Clin Microbiol 2006, 44(8):280I-2807.

33. Shaw M, Sande M van der, West B, Paine K, Ceesay S, Bailey R, Walraven G, Morison L, McAdam K: Prevalence of herpes simplex type 2 and syphilis serology among young adults in a rural Gambian community. Sex Transm Infect 200 I, 77(5):358-365.

34. Walraven G, Scherf C, West B, Ekpo G, Paine K, Coleman R, Bailey $R$, Morison $L$ : The burden of reproductive-organ disease in rural women in The Gambia, West Africa. Lancet 200I, 357(9263): || $6|-| \mid 67$.
35. Nilsen A, Mwakagile D, Marsden H, Langeland N, Matre R, Haarr L: Prevalence of, and risk factors for, HSV-2 antibodies in sexually transmitted disease patients, healthy pregnant females, blood donors and medical students in Tanzania and Norway. Epidemiol Infect 2005, 133(5):915-925.

36. Killewo J, Nyamuryekunge K, Sandstrom A, Bredberg-Raden U, Wall $S$, Mhalu F, Biberfeld G: Prevalence of HIV-I infection in the Kagera region of Tanzania: a population-based study. AIDS (London, England) 1990, 4(I I): I08I-I 085.

37. Ameli N, Bacchetti P, Morrow RA, Hessol NA, Wilkin T, Young M, Cohen M, Minkoff H, Gange SJ, Greenblatt RM: Herpes simplex virus infection in women in the WIHS: epidemiology and effect of antiretroviral therapy on clinical manifestations. AIDS (London, England) 2006, 20(7): 105 I- 1058.

38. Kebede $E$, Chamiso $B$ : Prevalence of syphilis in pregnancy in Addis Ababa. East Afr Med J 2000, 77(4):212-216.

39. Watson-Jones D, Oliff $M$, Terris-Prestholt $F$, Changalucha J, Gumodoka B, Mayaud P, Semakafu AM, Kumaranayake L, Gavyole A, Mabey $D$, et al: Antenatal syphilis screening in sub-Saharan Africa: lessons learned from Tanzania. Trop Med Int Health 2005, I 0(9):934-943.

40. Grosskurth H, Gray R, Hayes R, Mabey D, Wawer M: Control of sexually transmitted diseases for HIV-I prevention: understanding the implications of the Mwanza and Rakai trials. Lancet 2000, 355(9219): 1981-1987.

\section{Pre-publication history}

The pre-publication history for this paper can be accessed here:

http://www.biomedcentral.com/1471-2334/8/75/prepub
Publish with Bio Med Central and every scientist can read your work free of charge

"BioMed Central will be the most significant development for disseminating the results of biomedical research in our lifetime. "

Sir Paul Nurse, Cancer Research UK

Your research papers will be:

- available free of charge to the entire biomedical community

- peer reviewed and published immediately upon acceptance

- cited in PubMed and archived on PubMed Central

- yours - you keep the copyright
BioMedcentral 